\title{
Pentingnya Lingkungan dalam Pembelajaran Bahasa Indonesia
}

\author{
Shania Ramadhani Syafani/19016050 \\ shaniapadang123@gmail.com
}

Ramadhan et al (2019) mengemukakan pendidikan lingkungan hidup adalah usaha bersama yang secara sadar diselenggarakan untuk mengajarkan atau menarik perhatian manusia tentang bagaimana lingkungan alam berfungsi dan bagaimana manusia tersebut dapat mengelola dan melindunginya. Pendidikan ini berlangsung dalam praktik mencari kreativitas dan penemuan, serta eksplorasi realitas tanpa disadari. Mengembangkan pengetahuan tentang signifikansi ilmiah dan sosial lingkungan adalah langkah pertama dalam pembentukan masyarakat yang ramah lingkungan. Melalui pengetahuan dan kesadaran, muncul nilai dan sikap positif yang akan mendorong tindakan untuk melakukan penyesuaian gaya hidup dan kebiasaan konsumsi yang akan mengurangi beban yang kita tempatkan pada lingkungan. Ramadhan et al (2019)mengemukakan pendidikan lingkungan dapat membantu siswa untuk memikirkan kembali hubungan antara manusia dan lingkungan, mulai memahami lingkungannya, menyadari masalah lingkungan dan mempertimbangkan masalah lingkungan yang berkaitan dengan kehidupan mereka.

Suhardi et al (2019) mengungkapkan pemerolehan bahasa pertama sangat berkaitan dengan perkembangan sosial dan pembentukan identitas sosial, hal ini didapat melalui lingkungan. Ramadhan et al (2019) mengungkapkan masalah lingkungan secara inheren tidak dapat dipisahkan dari kesadaran lingkungan, nila-nilai dan sikap masyarakat.

Chaer (2007: 6-7) menyatakan bahwa kosakata yaitu, (1) semua kata yang terdapat dalam suatu bahasa, (2) katakata yang dikuasai oleh seseorang atau sekelompok orang dalam lingkungan yang sama, (3) kata-kata yang digunakan dalam suatu bidang kegiatan atau ilmu pengetahuan, (4) sejumlah kata dan suatu bahasa yang disusun secara alfabetis beserta dengan jumlah penjelasan dengan maknanya, dan (5) semua morfem yang ada dalam suatu bahasa. Jadi, dapat disimpulkan bahwa kosakata adalah perbendaharaan kata dan penguasaan sejumlah kata oleh seseorang dalam bahasa dan masyarakat bahasa tertentu dan dalam suatu bidang ilmu pengetahuan dengan penjelasan dan batasannya secara singkat dan praktis. Berdasarkan hal itu, perlu dibatasi penelitian kosakata siswa per bidang untuk melihat penguasaan kosakatanya pada masing-masing bidang ilmu pengetahuan khususnya bidang lingkungan hidup.

Diyanto, 2013; Satriani, (2012). Trianto (2009) mengemukakan bahwa "pembelajaran kontekstual Contextual Teaching and Learning (CTL) adalah suatu konsep pembelajaran yang membantu guru menghubungkan antara materi yang diajarkan dengan situasi dunia nyata siswa dan mendorong siswa untuk membuat hubungan antara pengetahuan yang dimiliki dengan penerapannya dalam kehidupan. -pan mereka sehari-hari, yang melibatkan komponen utama tujuh dari pengajaran yang efektif, yaitu:. konstruktivisme, pertanyaan, penyelidikan, pembelajaran masyarakat, pemodelan dan penilaian otentik.

Menurut Sari, Ramadhan, dan Rasyid (2018:447), membaca pemahaman bertujuan untuk memperoleh pemahaman yang lebih mendalam dari gagasan-gagasan yang terdapat dalam suatu bahan bacaan. Faktor utama yang paling menimbulkan permasalahan kemampuan membaca pemahaman adalah proses pembelajaran membaca yang belum efektif. Guru adalah komponen yang sangat menentukan dalam implementasi suatu strategi dalam mengefektifkan proses pembelajaran. Keberhasilan implementasi suatu strategi pembelajaran tergantung pada 
kepiawaian guru dalam menggunakan metode, teknik, dan taktik mengajarnya.

Terkait hubungan kreativitas siswa dengan lingkungannya, Munandar (dalamPilianget al, 2014) menyatakan bahwa kreativitas merupakan hasil interaksi individu dengan lingkungannya, maka tampak jelas bahwa kreativitas individu sangat ditentukan oleh dorongan atau motivasi dari dalam diri dan lingkungannya. Hal-hal yang telah disebutkan sebelum ini nantinya akan berhubungan dan berpengaruh terhadap hasil belajar siswa. Pernyataan tersebut sejalan dengan pendapat Zulhafizh et al (2013) yang menyatakan bahwa sikap dan motivasi belajar siswa berkontribusi dengan hasil belajarnya, yakni bahasa Indonesia.

Menurut Sukma (2019) guru hendaknya memberikan motivasi kepada siswa, melalui motivasi tersebut seorang guru dapat menciptakan berbagai pengalaman belajar bagi siswa. Indriyani et.al (2019) menyatakan literasi siswa perlu ditingkatkan terutama literasi baca tulis. Kemudian, juga perlu mengetahui bagaimana pelaksanaan literasi yang telah dilaksanakan di sekolah. Sukma (2020) mengungkapkan penanaman karakter penting ditanamkan sejak siswa masih duduk dibangku sekolah dasar. Penanaman karakter dapat dilakukan dalam proses pembelajaran di sekolah. Banyaknya keragaman karakter dan kebiasaan siswa di sekolah berasal dari latar belakang keluarga yang berbeda merupakan pengaruh besar sehingga menimbulkan hal-hal buruk dari karakter anak yang buruk.

Berdasarkan angket yang penulis sebarkan mengenai "Pentingnya Lingkungan dalam Pembelajaran Bahasa Indonesia" kepada mahasiswa Universitas Negeri Padang semester 5, mahasiswa Universitas Andalas semester 5, mahasiswa Universitas Islam Negeri Imam Bonjol Padang semester 5 dan 7, mahasiswa Institut Pertanian Bogor semester 5, mahasiswa Poli Teknik Negeri Padang semester 3, 5, dan 7, mahasiswa Institut Teknologi Padang semester 5, mahasiswa Politeknik Kesehatan Kementrian Kesehatan Padang semester 5, mahasiswa Keperawatan Stikes Alifah Padang semester 5, Mahasiswa STIKes Mercubaktijaya Padang semester 5, dan mahasiswa Sekolah Tinggi Kepeguruan dan Ilmu Pendidikan semester 5. Dari jumlah keseluruhan 43 responden yang ikut serta mengisi angket tersebut lebih dominan perempuan 36 responden dan laki-laki 7 responden dengan persentase 83,7\%perempuan, 16,3\%laki-laki.

Hasil dari data angket yang telah dilakukan melalui google form tersebut dapat dilihat sebagai berikut. Pernyataan pertama "Dalam melakukan komunikasi diperlukannya suatu bahasa, dalam penerapannya, bahasa memiliki peranan penting dalam kehidupan manusia" 60,5\% menyatakan sangat setuju, 37,2\% menyatakan setuju, 2,3\% menyatakan kurang setuju, dan0\%menyatakan tidak setuju. Pernyataan kedua "Pemanfaatan lingkungan adalah menggunakan alam yang ada disekitar kita, baik interaksi antara faktor biotik (hidup) dan faktor abiotik (tak hidup)untuk pembelajaran" 62,8\% menyatakan sangat setuju, 34,9\% menyatakan setuju, 2,3\%menyatakan kurang setuju, dan 0\% menyatakan tidak setuju. Pernyataan ketiga "Pembelajaran bahasa Indonesia berkaitan erat dengan kondisi lingkungan sekitarnya, terutama lingkungan berpengaruh untuk perkembangan bahasa anak" 58,1\% menyatakan sangat setuju, 39,5\% menyatakan setuju, 2,4\% menyatakan kurang setuju, dan 0\% menyatakan tidak setuju. Pernyataan keempat "Pengenalan pendidikan lingkungan penting untuk dimasukkan dalam pembelajaran Bahasa Indonesia guna menumbuhkan kesadaran peserta didik dalam menjaga lingkungan sekitar" 65,1\% menyatakan sangat setuju, 34,9\% menyatakan setuju, 0\% menyatakan kurang setuju, 0\% menyatakan tidak setuju. Pernyataan kelima "Guru bisa dan boleh mengaitkan antara teks-teks yang ada dalam pembelajaran bahasa Indonesia dengan contoh lingkungan" $74,4 \%$ menyatakan sangat setuju, 23,3\% menyatakan setuju, 2,3\% menyatakan kurang setuju, dan 0\% menyatakan tidak setuju. Pernyataan keenam "Pendidikan lingkungan dapat membuat siswa berfikir secara kritis dan kontekstual, cara berfikir yang kritis dan kontekstual ini berpengaruh nantinya terhadap pembelajaran bahasa Indonesia" 62,8\% menyatakan sangat setuju, 37,2\% menyatakan setuju, $0 \%$ menyatakan kurang setuju, dan $0 \%$ menyatakan tidak setuju. Pernyataan ketujuh "Pemakaian bahasa berkaitan 
erat dengan hubungan sosial antar penutur yang berada di tengah-tengah masyarakat" $67,4 \%$ menyatakan sangat setuju, 30,2\% menyatakan setuju, 2,4\% menyatakan kurang setuju, dan 0\% menyatakan tidak setuju. Pernyataan kedelapan"Kemampuan berbicara dan memahami bahasa dipengarui oleh faktor lingkungan" 58,1\%menyatakan sangat setuju, 34,9\% menyatakan setuju, 7\% menyatakan kurang setuju, dan0\%menyatakan tidak setuju. Pernyataan kesembilan "Cerita legenda "Batu Batangkup" merupakan cerita legenda dari daerah Riau" 30,2\% menyatakan sangat setuju, 67,4 menyatakan setuju, 4,7\%menyatakan kurang setuju, dan 0 menyatakan tidak setuju. Pernyataan kesepuluh "Penggunaan media literasi dalam pembelajaran bahasa Indonesia berbasis lingkungan dapat meningkatkan kesadaran peserta didik akan lingkungan" 58,1\% menyatakan sangat setuju, 41,9\% menyatakan setuju, $0 \%$ menyatakan kurang setuju, dan 0 menyatakan tidak setuju.

Dari hasil penyebaran angket yang telah dilakukan, dapat penulis simpulkan bahwa lingkungan memiliki peranan penting dan manfaat yang besar dalam pembelajaran Bahasa Indonesia. Terbukti dari respone para responden yang menganggap lingkungan sangat penting dalam pembelajaran Bahasa Indonesia, baik itu kalangan masyarakat, terutama mahasiswa dan pelajar. Menurut penulis, kesadaran masyarakat, mahasiswa, dan siswa terhadap pentingnya lingkungan dalam pembelajaran Bahasa Indonesia sudah dapat dikategorikan baik, walaupun masih ada beberapa masyarakat yang masih mengabaikannya, tetapi dengan sosialisasi yang terus menerus kepada masyarakat dapat mengubah pandangan masyarakat, dengan begitu dapat memudahkan guru dan siswa dalam mengajarkan dan memahami materi Bahasa Indonesia yang dapat memotivasi siswa sehingga mereka memiliki ide yang kreatif, berprestasi, dan memiliki manfaat bagi lingkungannya dan Negara. 


\section{DAFTAR PUSTAKA}

Ramadhan. S., Elfia Sukma., dan Vivi Indriyani. (2019). Environmental education and disaster mitigation through language learning. IOP Conference. Series: EarthandEnvironmental Science, 314, p. 1-9.

Guci. Ra., Syahrul R., Nursaid. (2016). Korelasi Penguasaan Kosakata Bidang Lingkungan Hidup dengan Menulis Karangan Argumentasi. Jurnal Pendidikan Bahasa dan Sastra Indonesia, Vol. 5 No. Seri B 169-174

Setiawati, Kurnia Nur., Syahrul Ramadhan., dan Erizal Gani (2018). The Ef ect of Contextual Teaching and Learning Model and Motivation towards Skill of FableText Writing. ICLLE Advances in Social Science, Education and Humanities Research, volume 263.

Putri, Diana dan Syahrul R. (2019). Korelasi Keterampilan Membaca Pemahaman dan Keterampilan Menulis Teks Laporan Hasil Observasi Siswa Kelas VII SMP Negeri 4 Pariaman. Jurnal Pendidikan Bahasa dan Sastra Indonesia, 8(1), seri A62-69.

Piliang, Wilda S. H., Atmazaki, dan Syahrul Ramadhan. (2014). Kontribusi Kemampuan Apresiasi Sastra dan Berpikir Kreatif terhadap Keterampilan Bermain Drama pada Siswa Kelas XII IPS SMA Negeri 2 Rengat Kabupaten Indragiri Hulu. Jurnal Bahasa, Sastra dan Pembelajaran, 2(2), 7587.

Zulhafizh, Atmazaki, dan Syahrul Ramadhan. (2013). Kontribusi Sikap dan Motivasi Belajar Siswa terhadap Hasil Belajar Bahasa Indonesia. Jurnal Bahasa, Sastra dan Pembelajaran, Volume 1, Nomor 2, Halaman 13-28.

Ramadhan, S., Elfia Sukma, dan Vivi Indriyani. (2019). Persepsi Guru terhadap Penggunaan Bahan Ajar Bahasa Indonesia dengan Perangkat Seluler dan Aplikasi Edmodo. Seminar Internasional Riksa Bahasa.

Sukma E, dan VP Azrianti. (2020). Instilling Positive Characters in Students Using Folker in the Macro media Application. Advances in Social Science, Education and Humanities Research, Volume 485.

Ip, Suhardi, Syahrul Ramadhan, Yasnur Asri. (2019). Pemerolehan Bahasa Pada Anak Usia Dini. Jurnal Obsesi: Jurnal Pendidikan Anak Usia Dini. Vol 3, Halaman 263-273.

Sukma E. Et.al. (2019). Problem in Oral Language Teaching In Primary School. AdvancesinSocial Science. Education and Humanities Research, Volume 301. 